Faculdade

de Ciências Econômicas UFRGS

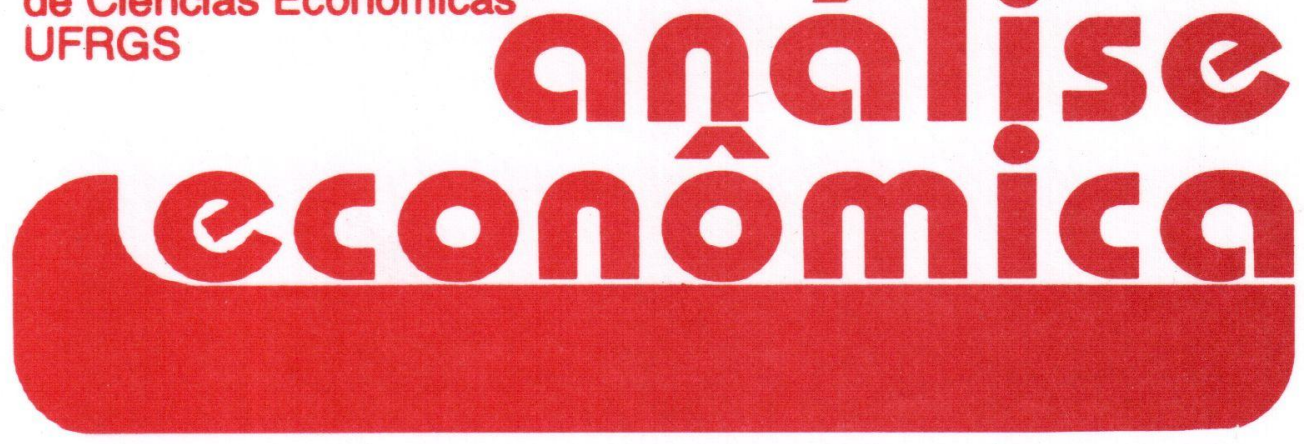

- Finance and Growth:

is Schumpeter Right?

- Philip Arestis

- Panicos Demetriades

- Repensando a

Revolução Marginalista

- Ricardo Luis C. Feijó

- O Papel dos

Rendimentos Crescentes

na Localização Econômica

- Paulo Augusto P. de Britto

- Credibilidade e Mercado Secundário da Dívida Externa Brasileira

- Paulo Calderon

- Rosa Fontes

- Fronteira de Eficiência sob Condições de Risco

- Luís A. de Araújo

- José Vicente Caixeta Filho

- A Criação de

Municípios e seu Impacto na

Qualificação do Espaço Urbano

- Maria Conceição B. Scussel

- Um Estudo Crítico das Relações entre as Poupanças Privada,

Pública e Nacional

- Martin R. Cavalcanti

- Joanílio R. Teixeira
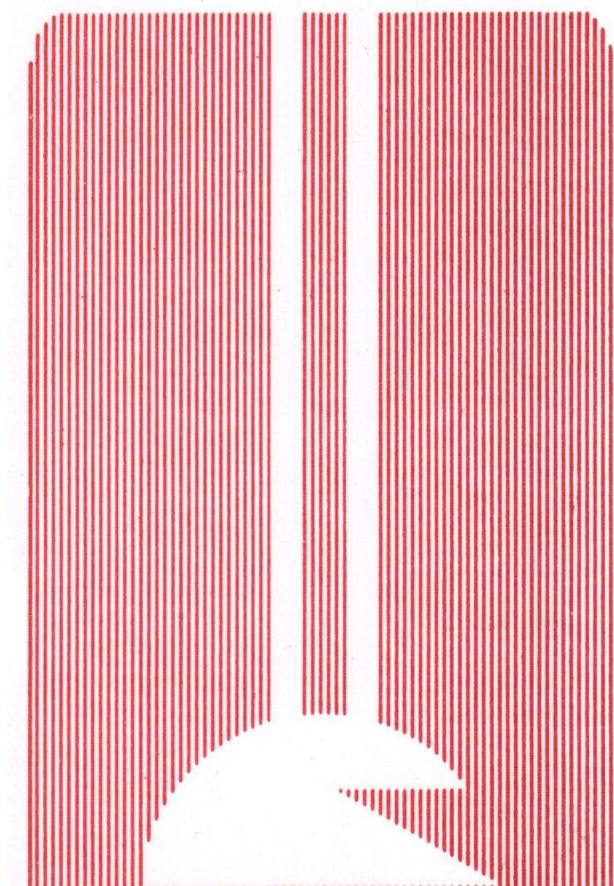

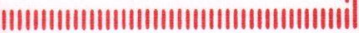

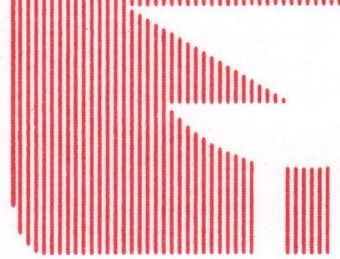

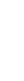


UNIVERSIDADE FEDERAL DO RIO GRANDE DO SUL

Reitora: Prof ${ }^{\mathrm{a}}$. Wrana Maria Panizzi

FACULDADE DE CIÊNCIAS ECONÔMICAS

Diretora: Prof ${ }^{\mathrm{a}}$. Otilia Beatriz Kroeff Carrion

CENTRO DE ESTUDOS E PESQUISAS ECONÔMICAS

Diretor. Prof. Fernando Ferrari Filho

DEPARTAMENTO DE CIÊNCIAS ECONÔMICAS

Chefe: Prof. Luiz Alberto Oliveira Ribeiro de Miranda

CURSO DE PÓS-GRADUAÇÃO EM ECONOMIA

Coordenador. Prof. Marcelo Savino Portugal

CURSO DE PÓS-GRADUAÇÃO EM ECONOMIA RURAL

Coordenador. Prof. Carlos Guilherme A. Mielitz Netto

CONSELHO EDITORIAL: Achyles B. Costa, Aray M. Feldens, Carlos A. Crusius, Carlos G. A. Mielitz Netto, Eduardo A. Maldonado Filho, Eduardo P. Ribeiro, Eugênio Lagemann, Fernando Ferrari Filho, Gentil Corazza, Marcelo S. Portugal, Nali J. Souza, Otília B. K. Carrion, Paulo A. Spohr, Paulo D. Waquil, Pedro C. D. Fonseca, Roberto C. Moraes, Ronald Otto Hillbrecht, Stefano Florissi, Eleutério F. S. Prado (USP), Fernando H. Barbosa (FGV/RJ), Gustavo Franco (PUC/RJ), João R. Sanson (UFSC), Joaquim P. Andrade (UnB), Juan H. Moldau (USP), Paul Davidson (Univ. of Tennessee), Werner Baer (Univ. of Illinois).

COMISSÃO EDITORIAL: Fernando Ferrari Filho, Gentil Corazza, Paulo Dabdab Waquil, Marcelo Savino Portugal, Roberto Camps Moraes.

EDITOR: Eduardo Augusto Maldonado Filho

EDITOR ADJUNTO: Gentil Corazza

SECRETARIA: Revisão de textos: Vanete Ricacheski.

FUNDADOR: Prof. Antônio Carlos Santos Rosa

Os materiais publicados na revista Análise Econômica são da exclusiva responsabilidade dos autores. É permitida a reprodução total ou parcial dos trabalhos, desde que seja citada a fonte. Aceita-se permuta com revistas congêneres. Aceitam-se, também, livros para divulgação, elaboração de resenhas e recensões. Toda correspondência, material para publicação (vide normas na terceira capa), assinaturas e permutas devem ser dirigidos ao seguinte destinatário:

PROF. EDUARDO AUGUSTO MALDONADO FILHO

Revista Análise Econômica - Av. João Pessoa, 52 CEP 90040-000 PORTO ALEGRE - RS, BRASIL

Telefones: (051) 316-3324 e 316-3440 - Fax: (051) 316-3990 rae@vortex.ufrgs.br 


\title{
FINANCE AND GROWTH: IS SCHUMPETER `RIGHT'?
}

\author{
Philip Arestis ${ }^{*}$ \\ Panicos Demetriades
}

\section{RESUMO}

Este artigo questiona a causalidade entre o desenvolvimento financeiro e o crescimento econômico. Demonstra-se que os resultados obtidos em estudos econométricos recentes entre paises, do tipo popularizado por Barro, apresentam sérias limitações. Argumenta-se que fatores institucionais, que são específicos a cada pais, podem influenciar a natureza da causalidade entre desenvolvimento financeiro e o crescimento econômico, e, por isso, pode se esperar que essa relação varie entre os paises. Sugere - se que, ao contrário dos estudos do tipo cross-section, o estudo de país para país dessa questão é muito mais promissora para se compreender a relação entre o desenvolvimento financeiro e o crescimento econômico.

Cód. AEA: 111 Palavras - Chave: desenvolvimento financeiro, crescimento econômico

\section{ABSTRACT}

This paper examines the question of causality between financial development and economic growth. We demonstrate that results obtained from recent cross-section country studies, of the type popularised by Barro, suffer from serious shortcomings. We argue that country specific institutional factors are likely to influence the causal nature of the relationship between financial development and economic growth, which is, therefore, expected to vary across countries. We suggest, instead, that a country by country study of the problem in hand is by far more promising.

AEA Cód: 111

Key words: Financial Development, Economic Growth

* Department of Economics, University of East London, Longbridge Road, Dagenham, Essex RM8 2AS, UK. E-mail address: p.arestis@uel.ac.uk

** The Business School, South Bank University, 103 Borough Road, London SE1 OAA, UK. E-mail address: demetrpo@sbu.ac.uk

\begin{tabular}{|l|l|l|l|r|}
\hline ANÁLISE ECONÔMICA & ANO 16 & N.30 & SETEMBRO/98 & p. 5-21 \\
\hline
\end{tabular}




\section{1.- INTRODUCTION ${ }^{*}$}

The relationship between financial development and economic growth has received a great deal of attention throughout the modern history of economics. Its roots can be traced in the work of Schumpeter (1959, first published in 1911) who argued that financial services are paramount in promoting economic growth. In this view production requires credit to materialise, and one "can only become an entrepreneur by previously becoming a debtor..... What [the entrepreneur] first wants is credit. Before he requires any goods whatever, he requires purchasing power. He is the typical debtor in capitalist society" (Schumpeter, p. 102). In this process, the banker is the key agent. Schumpeter (1959) is very explicit on this score: "The banker, therefore, is not so much primarily the middleman in the commodity 'purchasing power' as a producer of this commodity ..... He is the ephor of the exchange economy" (p. 74).

In contrast Robinson (1952) argued that financial development follows growth, and articulated this causality argument by suggesting that "where enterprise leads finance follows" (p. 86). Robinson and other followers of Keynes (1936), for example Chick (1983, 1986), would argue that although growth may be constrained by credit creation in less developed financial systems, in more sophisticated systems finance is viewed as endogenous responding to demand requirements. This line of argument suggests that the more developed a financial system is the higher the likelihood of growth causing finance. In Robinson's (1952) view then, financial development follows growth or, perhaps, causation may be bidirectional; in either case Schumpeter might thus not be 'right'.

Building on the work of Schumpeter, McKinnon (1973) and Shaw (1973) propounded the 'financial liberalisation' thesis in 1973 arguing that government restrictions on the banking system restrain the quantity and quality of investment. More recently the endogenous growth literature has suggested that financial intermediation has a positive effect on steady-state growth (see Pagano, 1993, for a survey), and that government intervention in the financial system has a negative effect on the equilibrium growth rate (King and Levine, 1993b). These developments can be considered as an antidote to the thesis put forward by Modigliani and Miller (1958) that the way firms finance themselves is irrelevant (their 'irrelevance propositions'), which is consistent with the perception of financial markets as independent entities from the rest of the economy, so that finance and growth are unrelated.

The difficulty of establishing the direction of causality between financial development and economic growth was first identified by Patrick (1966) and further developed by McKinnon (1988) who argued that: " Although a higher rate of financial growth is positively correlated with successful real growth, Patrick's (1966) problem remains unresolved: What is the cause and what is 
the effect? Is finance a leading sector in economic development, or does it simply follow growth in real output which is generated elsewhere?" (p. 390). The causality between financial development and economic growth is, therefore, a controversial issue which could be resolved potentially by resorting to empirical evidence. A recent attempt to explore this aspect of the debate has been attempted by King and Levine (1993a) who have argued that Schumpeter (1959) may very well have been 'right' with the suggestion that financial intermediaries promote economic development. Using data for a number of countries, covering the period 1960 to 1989, they find that "higher levels of financial development are significantly and robustly correlated with faster current and future rates of economic growth, physical capital accumulation and economic efficiency improvements" (op.cit., pp. 717-718). From these results the authors conclude that the link between growth and financial development is not just a contemporaneous correlation and that "finance seems importantly to lead economic growth" (op. cit., p. 730).

Our paper attempts to tackle two issues, both emanating from the King and Levine (1993a) study. The first is to show that although King and Levine (1993a) attempted to tackle in an ingenious way an issue which has plagued the empirical literature on the relationship between finance and development for a long time, their causal interpretation is based on a fragile statistical basis. Specifically, in section 2 we show that once the contemporaneous correlation between the main financial indicator and economic growth has been accounted for, there is no longer any evidence to suggest that financial development helps predict future growth. The second issue is to demonstrate that the cross section nature of the King and Levine (1993a) data set cannot address the question of causality in a satisfactory way. We proceed by offering a theoretical framework which suggests that causality patterns may vary across countries as a result of different institutional characteristics. This leads to the suggestion that these institutional characteristics should be the guiding pronciple in any work which hopes to throw any light on the question of causality between finance and growth. The final section summarises and concludes.

\section{2 - INITIAL FINANCIAL DEVELOPMENT AND GROWTH RECONSIDERED}

The conclusion of King and Levine (1993a) is based on the finding that "the predetermined component of financial development is a good predictor of long-run growth over the next 10 to 30 years" (p. 719). King and Levine present their fundamental results in Table VIII (p. 731) where data for 57 countries are utilised. Table VIII contains four equations in which the dependent variable is the average rate of real per capita GDP growth during 1960-1989 (GYP). ${ }^{1}$ Independent variables vary according to specification, but all specifications include the initial (1960) level of the main financial indicator (M2Y in 1960). The 
results of their regressions are reproduced here in Table 1 as equations $1 a, 2 a$, $3 a$ and $4 a$, where the number of observations is $57, C=$ constant, $L Y O=\log$ of initial real per capita GDP in 1960, LSEC $=\log$ of secondary school enrolment rate in 1960, GOV = the ratio of government consumption to GDP, $\mathrm{PI}=$ inflation rate, $\mathrm{TRD}=$ the ratio of imports plus exports to GDP, M2Y = the value of financial depth over the period 1960-1989 (the ratio of M2 to GDP, where M2 is defined as the sum of currency held outside the banking system and demand and interest-bearing liabilities of banks; this is the same variable as that of King and Levine labelled as LLY). In the first three equations the coefficient of M2Y in 1960 is significant at the $99 \%$ level, and at the $95 \%$ level in the fourth equation. The authors also claim that their findings are not sensitive to changes in specification and sample. However, this needs some qualification in view of the results in their Table VIII which clearly show that the statistical significance of M2Y in 1960 declines as dummies are included, not to mention that in specification $4 a$ it is only marginally significant. It is on the basis of these results that King and Levine (1993a) reached the conclusion that 'finance leads economic growth'.

Furthermore, and interestingly enough, the equations in the King-Levine Table VIII (and IX) do not include the contemporaneous level of the financial indicator as an independent variable. Thus, the equations may be misspecified if the true model contains the contemporaneous rather than the initial level of financial development. However, given that financial indicators are strongly correlated across time (King and Levine report these in Table VI; we find a correlation coefficient of 0.90 between M2Y and M2Y in 1960) an alternative interpretation is that $\mathrm{M} 2 \mathrm{Y}$ in 1960 is acting as a proxy for the missing variable M2Y. If this is true then the positive association between M2Y in 1960 and subsequent economic growth is nothing more than a contemporaneous correlation. In fact, King and Levine (1993a) report regressions in Table VII which also contain the contemporaneous level of M2Y, although the results in this table are not comparable with those in their Table VIII. They are based on a different sample, specifically on 77 observations as compared to 57 in Table VIII, in addition to the more obvious difference that the results in Table VII emanate from a different specification and a different objective from those of Table VIII which attempt to tackle the causality issue.

In order to investigate the possibility of misspecification, we employ the precise data and sample as in King and Levine (1993a), Table VIII. ${ }^{2}$ Two sets of regressions are reported in each case. The first $(1 b, 2 b, 3 b, 4 b)$ replaces M2Y in 1960 with M2Y. ${ }^{3}$ The second (1c, 2c, 3c, 4c) utilises both variables in each equation. The results are revealing. In all four cases the substitution of M2Y in 1960 by M2Y improves matters: the $R^{2}$ is higher and all the other variables retain their significance and in some cases they even improve it (GOV in 1960 in equations 2b, 2c, 3b and 3c, as well as the Latin America dummy in 
equation $4 \mathrm{c}$ ), or they are no worse when compared with the equation that contains M2Y in 1960. Contrary to the King/Levine results where the statistical significance of M2Y in 1960 declines, the contemporaneous M2Y variable improves its statistical significance with the addition of a variety of dummies. In addition, the significance of the M2Y variable in $4 \mathrm{~b}$ (at the $99 \%$ level) is superior to that of M2Y in 1960 in equation 4a (at the $95 \%$ level). When both M2Y in 1960 and M2Y are utilised in the same equation, M2Y retains its significance whilst M2Y in 1960 loses its significance completely and its sign changes to negative thus becoming totally useless as a variable influencing GYP. 'Finance does not lead economic growth', now!

An additional problem in interpreting the King and Levine correlations in a causal sense is posed by the nature of their data set which, being a set of pooled data, cannot allow the possibility of different countries exhibiting different patterns of causality, which may reflect differences in institutional structure across countries. The contrast between German and British banks, for example, suffices to illustrate the validity of this point. Typically, in Germany banks are actively involved in financing industrial investment activity. They provide long-term funding, managerial direction and co-ordinate the investment plans of the group of firms they are associated with. In Britain there is a relatively low involvement of financial institutions in industrial finance. ${ }^{4}$ It is for this reason that a highly developed and independent capital market exists in Britain, whereas in Germany opportunities for such a market are far more limited. It is then possible to argue that on a priori grounds we expect that in Germany expansion of the banking system may lead economic growth whilst the opposite may be true for Britain. To the extent that this argument can be accepted, it follows that the broad brush notion that finance leads (or follows) growth in a 'representative' country is of limited usefulness, particularly from an economic policy point of view. It is for this very reason that we wish to explore further the causality issue using the institutional dimension, an aspect taken up in the section that follows.

\section{3 - MONEY, FINANCE AND CAUSALITY: CONCEPTUAL ISSUES}

Our discussion so far indicates clearly that causality is still a very open question and that it could very well vary from country to country. In an attempt to account for both of these issues we offer in this section a conceptual framework which embraces the views summarised in the introductory section of this paper. This framework is based on the notion that the institutional differences that exist amongst the financial systems of the various countries in the world are of paramount importance. Ever since Gerschenkron (1962), there has been a growing literature which emphasises these differences in the financial systems of countries (see, for example, Frankel and Montgomery, 
1992). We adopt the taxonomy established by Gerschenkron (1962) which we find convenient and appropriate for our purposes. This taxonomy divides financial systems into two categories: the 'bank-based' and the 'capital-marketbased' financial systems (for a more recent analysis that adopts this distinction, see Mayer, 1987).

The main features of the 'bank-based' systems are the close involvement of their banks with industrial firms, and the relatively low importance and degree of development of their capital markets. There is a small number of banks involved with the long-term financing of investment which rely on non-market arrangements in the organisation of their financial institutions. Ownership of companies is characterised by a small number of shareholders with large share stakes. Control of companies is retained within the corporate sector with the small shareholders having very limited control. Companies have committed and knowledgeable shareholders with a strong bank presence on management boards. There are very few mergers and takeovers, with management being accountable and removed or changed whenever it is proved to underperform, without the heavy cost and trauma of hostile takeovers. Banks in these financial systems continue to operate despite the emergence of globalisation and financial liberalisation which have gained momentum since the collapse of the Bretton Woods in the early 1970s. It must be said, however, that these developments pose new challenges to the viability of the 'bank-based' financial systems. Be that as it may, the main characteristic of 'bank-based' financial systems is that companies rely heavily on bank loans and not so much on equity, with banks exercising an important monitoring role. Thus, banks play a key role in the process of growth and development. This role of the banks tends to contain 'short termism' and provides a safety valve by changing or removing management at an early stage when trouble is in prospect. We find such systems in Japan, Germany, and S. Korea. However, a growing literature is rather sceptical of the proposition that the German financial system is as "bankbased' as it has just been argued. Edwards and Fischer (1994) have suggested that in the 1970s and 1980s German firms relied less on bank loans as a source of finance than, for example, did UK firms (where the financial system is more 'capital-market-based'). They have also questioned the proposition that the involvement of German banks in industry is as strong as it is usually claimed. Others have propounded the view that the influence of the German banks on the economy has been overestimated (Schneider-Lenne, 1994). But the point remains that roughly two-thirds of bank loans to industry in Germany are long-term (op. cit., p. 293).

By contrast, the 'capital-market-based' financial systems, typically the UK and USA financial systems, are characterised by highly developed capital markets and banks which have relatively low involvement in the allocation of funds or ownership of financial assets. Most external long-term funds are raised 
from the capital-market which is an open and highly active market in encouraging mergers and takeovers. This latter aspect is viewed as an effective way of imposing accountability on management since shareholders find it difficult to impose their opinions except in crises. Ownership of companies is of a large number of shareholders with relatively small share stakes. Control resides outside the corporate sector, primarily with non-bank financial institutions (pension funds and insurance companies for example). Another more related and important aspect of these financial systems is that finance has become one element of an international financial system. In this sense it is the international circuits that dominate them rather than their links with domestic industries.

In the UK and USA capital-markets are relatively well-developed and provide substantial amounts of the financing of industry. The relatively large size of these markets reflects a large number of companies coming to the market for the first time; for example in the UK small and medium-sized companies raised substantial amounts of new equity funds in the 1980s (Mayer, 1994). Not that banks do not have any role to play at all in this respect. Banks are a source of finance for industry. In the USA firms with under 100 million assets cover 75 per cent of their financing needs through bank borrowing, a share which falls to 13 per cent, however, as size increases to more than $\$ 1$ billion in assets (Fazzari et al, 1988). Banks in the UK finance small and medium-sized companies (McWilliams and Sentance, 1994), but they are not involved in the provision of long-term finance (two-thirds of bank loans to industry are short-term; see Schneider-Lenne, 1994) nor are they represented on company boards as banks do in the 'bank-based' financial systems. Actually, in the 1970s there was concern in the UK about the willingness of banks to finance industry. So much so that the Wilson Committee (HMSO, 1980) proposed the establishment of a new investment institution to meet industry's financial needs. In the 1980s financial deregulation and the consequent increase in bank lending, merger and takeover activities for corporate control and the willingness of industry to finance itself more through retained profits and bank lending (to small and medium-sized companies than to large corporations; see Hughes, 1994, for an example) than previously, meant that dependence on the capital markets for finance subsided, "although the revival for rights issues in the early 1990 s points to the role of capital raising as still being of importance" (Dimsdale, 1994, p. 23). Dimsdale (op. cit.) also suggests that "The feast of loans in the mid-1980s has been followed by stringency in lending in the early 1990s, leading to vigorous complaints, particularly from smaller companies. The present difficulties are not unprecedented as observers of the over-extension of credit by secondary banks in the early 1970s, following the first wave of deregulation, will remember" (p. 34). Merger and takeovers for corporate control were active in 
both the UK and USA particularly in the 1980 s, but were a rare phenomenon in the 'bank-based' financial system (see, Bannock, 1990, for relevant evidence). Banks have provided much of the finance for takeovers in the UK and USA and made possible an active market for corporate control. By contrast in 'bankbased' financial systems the close link between banks and industry provides protection against hostile takeovers.

An interesting implication for the distinction between 'bank-based' and capital-market-based' financial systems, emanates from recent empirical work on the overall contribution of internal finance and various forms of external finance to industry (Mayer, 1988, 1990, 1994, are good examples). There are three key characteristics in this respect, which are applicable to both financial systems: internal finance is the most important source of finance; banks are the most significant source of external finance; and securities markets do not provide large proportions of funds to industry. Although these findings tend to blur the distinction between the two financial systems, there are still crucial differences. In particular, the self-financing ratio is considerably higher for the UK and US than for Japan and France, with Germany being in an intermediate position. Bank-finance is more dominant in Japan than in the other countries, but in terms of sources of finance Germany should be grouped with the UK and US.

There are three problems which financial systems are expected to resolve: there are problems related to information, principal/agent relationships and uncertainty in financial markets. It is generally recognised that 'bank-based' financial systems resolve these problems more successfully than the 'capitalmarket-based' financial systems. They can thus promote longer time horizons, encourage financial stability and foster a framework for the implementation of successful economic policies. By contrast, the 'capital-market-based' financial systems encourage shorter time horizons since firms are primarily concerned with performance criteria as defined by the transactions-oriented capital markets. The source of financial uncertainty and fragility is embedded in the mismatch between debt commitments and income flows. This mismatch is due to finance being channelled to speculative purposes which is used to buy existing assets in the expectation of capital gains, rather than to productive purposes. Thus long-term finance dedicated to long-term productive investment reduces speculative activities. Clearly, 'bank-based' finance by encouraging long-term finance is expected to contain endemic financial fragility and uncertainty (see, for example, Poterba and Summers, 1992). The close relationship between financial and industrial capital in 'bank-based' financial systems implies that speculative finance does not exert significant influence on real economic activity as it does in 'capital-market-based' financial systems. 


\section{4 - MONEY, FINANCE AND DIRECTION OF CAUSALITY}

The analysis offered in section 3 indicates that the causality between financial intermediation and economic growth is likely to be either from finance to growth or bidirectional in the case of the 'bank-based' systems. In the case of 'capital-market-based' systems it is expected to be from growth to finance although a bidirectional relationship cannot really be ruled out. Bidirectionality becomes even more likely in both cases in view of the changes that have occurred in both financial systems, as these are chronicled by Mayer (1988, $1990,1994)$. Furthermore, when the role of government is examined this conclusion is reinforced. The government is expected to play a rather more limited role in administering prices and quantities in 'capital-market-based' than in 'bank-based' financial systems. Given the greater integration between financial and industrial firms, 'bank-based' financial systems are in a better position to implement successfully expansionary monetary policy and industrial strategy. In the capital-market-based' financial systems where financial firms are not directly linked to industry, the financial system is more independent and more likely to favour restrictive policies. In the UK and US this independence of the financial system has led to a strong international orientation thereby developing a formidable industry around international finance.

Under such circumstances stability and confidence in the currency is given top priority in 'capital-market-based' than in 'bank-based' financial systems. Zysman (1983) has demonstrated that in the UK and US 'capital-market-based" financial systems the government's role is limited, contrary to the Japanese and S. Korean 'bank-based' financial systems where the government participates actively in the allocation of credit to industry. Germany, Zysman argues, is in a unique position of a 'bank-based' financial system in which the government does not play an active role as in the case of Japan and $\mathrm{S}$. Korea. It follows from this analysis that in Japan and S. Korea the link between finance and growth is very close, with the causation running from finance to growth, if not bidirectional, and in the case of Germany more bidirectional. The UK and US are faced with weak links in terms of the causation between finance and growth, or growth may indeed cause finance, although in the case of the UK the causation may very well run from finance to growth in view of the analysis expounded above. An interesting case is that of the financial system in France which falls into an intermediate stage between 'bank-based' and 'capitalmarket-based" financial systems given the size of the capital markets and the degree of nationalisation of the banking system in this country. On the other hand, bank loans to industry as a percentage to GDP are significantly lower to that of, say, Spain's or indeed Germany's (see, for example Vinals et al, 1990, p. 184, for a relevant comparison); in any case, banks in France do not play an important role in the control of firms. In this sense it may very well be that the 
French system is nearer to the 'capital-market-based" rather than to the 'bankbased' financial system.

Global financial developments may have changed the link between finance and growth. Financial fragility in the world has increased for a number of reasons. Three may be mentioned: the collapse of Bretton Woods in the early 1970s; the Latin American debt crisis of the early 1980s; and the merger and takeover wave in the US and UK in the late 1980s. This increase of financial instability has weakened the transmission mechanism from policy instruments to policy targets and causality may very well have been affected. Also, the power of financial markets has increased substantially, so that the influence of financial markets overrides even electoral mandates. ${ }^{5}$ The ability of highly innovative financial markets to lower the costs of intermediation and circumvent regulations that impede profitable transactions, has been enhanced substantially. These considerations, essentially due to the globalisation of financial markets has meant that Central Banks are not as powerful as they used to be. Thus the integration of financial markets make it more difficult for any single country to conduct expansionary monetary policy - speculation will force the country to strengthen its currency. Integration and financial innovation make it more difficult for countries to use open-market operations to establish control over money and credit. In general terms difficulties arise in relation to domestic regulatory policies which diminish the ability of Central Banks to conduct autonomous monetary policy. These developments weaken the link of finance to growth, in particular in the case of the Federal Reserve System in view of the dominant role it has had on the international monetary scene. This consideration along with the fact that the US is the most advanced and mature country in the world imply that the link between finance and growth in this country may have become weaker. This would suggest that it may be more difficult to find a 'stable' relationship between finance and development in the USA than in other countries; or, indeed, that a wider definition for the financial indicator may be necessary than otherwise.

Not unrelated to these considerations is the case of another extremely interesting group of countries which we may loosely label as developing countries: examples include, India, Spain, Greece, Turkey, Chile, Mexico etc., which comprise a sub-category of countries with special characteristics. Clearly, the financial systems of these countries do not resemble the 'capitalmarket-based' financial system, nor do their banks have close links with industry in the way banks have in Japan. They may very well be somewhere nearer to the French financial system than to any other. One common characteristic of these countries is that their banking sectors were either nationalised, fully or partially, during the period under investigation, or else under the grip of national governments. Another common characteristic is that more recently they have gone through a process of 'financial liberalisation'. As 
part of these financial liberalisation policies there have been attempts to enlarge their capital markets. A further common characteristic is their reliance on international financial markets. The international integration of these markets implying a much more mobile capital, has altered the context of national industrialisation and nationalisation of financial systems. It has meant that short-term holdings of financial assets, domestic or international, provide higher and lower-risk returns than investment in long-term industrial expansion, thus promoting speculative-led expansions. International financial integration, therefore, tends to divert financial resources away from domestic industry thereby weakening the link between finance and development. These institutional aspects and their recent developments may have had important implications in terms of the expected causality between finance and investment. They suggest that bi-directionality should not be a surprising outcome if it were to emerge in the empirical analysis. The case of Mexico is a very good example of what is argued here (Chile, also, went through similar experiences). In the early 1980s bank nationalisation took place in Mexico which, however, was limited in the face of growing international capital mobility leading eventually to the 'financial liberalisation' policies of the late 1980s, most important of which were the relaxation of restrictions on foreign participation in the financial sector and the reprivatization of banks. A related implication of these policies has been the expansion of the stock market which has fuelled the recent speculation-led expansion in this country - the consequences of these developments is beyond the purpose of this paper. In any case in those developing countries where the family-firm is prominent, a common occurrence in many developing countries actually, causality may very well run from growth to finance. Family-firms are private firms which rely heavily on retained profits to finance investment, so that they are not faced with external financial constraints whenever they wish to expand.

Further special features which characterise the banking systems of these countries are pertinent. For most of the period under scrutiny financial institutions and markets in these countries were subjected to extensive regulations and financial controls. Interest rates were set administratively by the central banks, alongside credit rules and regulations. Domestic economic policies were actively pursued, which aimed to protect industrial activity in a conspicuously selective manner. A dirigiste control of credit by public sector banks was used over the period as an important means by the state to influence the private sector, but in most cases this was based on political expediency rather than on economic criteria. Capital markets in developing countries were shallow over the period under investigation, especially equity markets due to lack of institutional investors, so that the private sector depended heavily on the state-administered banking sector for both short-term and long-term capital which led to mushrooming of extensive informal' markets 
for credit. Inevitably, the outcome of those institutional arrangements was the development of segmented financial markets in developing countries. An important implication of those arrangements and the credit rationing ensued was that the need for 'political resolution of conflicts' became paramount, thus leading to what Singh (1995) has labelled as 'crony capitalism' whereby finance favours individuals and families with 'political standing' rather than promoting long-term industrial growth. A further consideration which is particularly pertinent to countries like Greece and Turkey, is that their banking systems are constrained in their lending in view of the alarming incidence of non-performing loans which tend to grow as their service is capitalised into new loans. As international banks infiltrate local markets they capture the more credit-worthy customers thus weakening further the position of the domestic banking system (Branson, 1990, pp. 123-126). ${ }^{6}$

These observations point to an important implication, that the relationship between finance and growth in these countries tends to weaken with causality moving away from 'finance causes growth' and tending more towards the 'finance follows growth' proposition. More recently, of course, 'financial liberalisation' policies have been pursued but still the banking systems of these countries functioned under some regulations. These comments are also pertinent in the case of Spain where banks play an important role in the financing of industry. Banks have been important shareholders as well as lenders to industrial firms. But the banking system in Spain is allegedly inefficient relatively to other European banking sectors (Vinals et al, 1990). The interbank market has been growing recently but so have capital markets, especially in the 1980s, but not as rapidly as the interbank market. However, what is particularly interesting in terms of recent experience is that Spain proceeded to adapt openness by liberalising capital flows before liberalising trade. As a result capital inflows increased substantially along with brisk multinational activity. These observations may account to some extent for the bidirectionality and the 'growth causes finance' results in our empirical investigation. In the past Spain's financial system had all the characteristics of the other developing countries as described earlier.

\section{5 - SUMMARY AND CONCLUSIONS}

We have considered in this paper the question of causality as a critique of a recent contribution by King and Levine (1993a) which does not consider the institutional factors of the countries examined. We then proceeded to account for the possibility of different financial structures by investigating causality in the case of countries which have a number of different institutional characteristics in their financial structures. The results in all cases tend to justify our claim for the importance of institutional details in this debate. 
The results of this study clearly suggest that in investigating causality between finance and growth, the financial system one is investigating is of paramount importance. Consequently, generalisations of the type of King and Levine (1993a) may be misleading and as such offer no help in answering questions on causality between finance and development. In a quantitative sense, this implies that time series analyses and data are much more relevant than cross-section. This is an aspect which we have dealt elsewhere (see, Arestis and Demetriades, 1997).

\section{NOTES}

* We would very much like to thank Khaled Hussein for generous research assistance. We would also wish to thank the participants to the Money, Macro and Finance Research Group for their comments at the meeting of the Group on 24 March, 1995. Bahram Pesaran and Malcolm Sawyer helped us sharpen some of the arguments in the paper and we are extremely grateful to both of them.

1. Table IX presents similar results obtained from pooled decade data, and a more comprehensive range of financial indicators.

2. We are extremely grateful to Robert King and Ross Levine who let us have their data as soon as we asked for them. All the regressions were run using the definitions and data of their study.

3. Equations $1 \mathrm{~b}, 2 \mathrm{~b}, 3 \mathrm{~b}$ and $4 \mathrm{~b}$ were also run using instrumental variables, with M2Y in 1960 being the instrument. The results were not significantly different from the ones reported in Table 1 where the OLS technique was utilised.

4. A substantial literature on the link between financial structure and investment has developed. See Frankel and Montgomery (1992) for a recent contribution.

5. Woodward (1994) offers the example of the Clinton Administration. The President is quoted as saying: "You mean to tell me that the success of the program and my reelection hinges on the Federal Reserve and a bunch ..... bond traders?" ( $p$ 84). Or, indeed, "Here we help the bond market and we hurt the people who voted us in" (p.91).

6. For countries like Greece the likelihood of this happening is even greater since there is in addition to what is noted in the text, the pressures emanating from EU membership (see Katselis, 1990, for further details and analysis). 


\section{REFERENCES}

BANNOCK, Graham. The Takeover Boom: An International and Historical Perspective, Papers prepared for the Inquiry into Corporate Takeovers in the UK No. 2, David Hume Institute: Edinburgh, 1990.

BRANSON, William H. Financial Market Integration, Macroeconomic Policy and SEM. In: BLISS, Christopher MACEDO, Jorge Braga de. (eds.). Unity With Diversity in the European Community: The Community's Southern Frontier, Cambridge: Cambridge University Press, 1990.

CHICK, Victoria. Macroeconomics After Keynes: A Reconsideration of the General Theory, Oxford: Philip Allan, 1983.

CHICK, Victoria. "The Evolution of the Banking System and the Theory of Saving, Investment and Interest". Economies et Societes, Serie MP, 3, 1986. Reprinted In: ARESTIS, Philip and DOW Sheila C. (eds). On Money, Method and Keynes: Selected Essays, Victoria Chick, London: Macmillan, 1992.

DIMSDALE, Nicholas $H$. The Need to Restore Corporate Accountability: An Agenda for Reform. In: DIMSDALE, Nicholas H. and PREVEZER, Martha. (eds). Capital Markets and Corporate Governance, Oxford: Claredon Press, 1994.

EDWARDS, Jeremy S.S. and FISCHER Karl An Overview of the German Financial System. In DIMSDALE, Nicholas H. and PREVEZER, Martha. (eds.). Capital Markets and Corporate Governance, Oxford: Claredon Press, 1994.

FAZZARI, Steven M., HUBBARD, G. and PETERSON, B.C. Financing Constraints and Corporate Investment. Brookings Papers in Economic Activity, v. 1, p. 141-195, 1988

FRENKEL, Allen and MONTGOMERY John. Financial Structure: An International Perspective. Brookings Papers in Economic Activity, v. 1, p. 257-297, 1992.

GERSCHENKRON, Alexander. Economic Backwardness in Historical Perspective, Cambridge, MA: Harvard University Press, 1962.

HMSO. Report of the Committee to Review the Functioning of Financial Institutions. Report Cmnd 7937, Wilson Committee, London: HMSO, 1980.

HUGHES, Alan. The 'Problems' of Finance for Small Businesses. In DIMSDALE, Nicholas $\mathrm{H}$. and PREVEZER, Martha (eds.). Capital Markets and Corporate Governance, Oxford: Claredon Press, 1994.

KATSELIS, Louca T. Economic Integration in the Enlarged European Community: Structural Adjustment in the Greek Economy. In BLISS, Christopher and MACEDO, Jorge Braga de (eds.). Unity With Diversity in the European Community: The Community's Southern Frontier, Cambridge: Cambridge University Press, 1990.

KEYNES, Maynard J. The General Theory of Employment, Interest and Money, London: Macmillan, 1936.

KING, Robert G. and LEVINE, Ross. Finance and Growth: Schumpeter Might Be Right, Quarterly Journal of Economics, CVIII, p. 717-737,1993a.

KING, Robert G. and LEVINE, Ross. Finance, Entrepreneurship and Growth, Journal of Monetary Economics, 32, p. 1-30, 1993b.

MAYER, Colin. The Assessment: Financial Systems and Corporate Investment, Oxford Review of Economic Policy, 3/4, p. i-xvi, 1987.

MAYER, Colin. New Issues in Corporate Finance. European Economic Review, 32, p. 1167$1189,1988$.

Financial Systems, Corporate Finance and Economic Development. In: HUBBARD, Robert (ed.). Asymmetric Information, Corporate Finance and Investment, New York: National Bureau of Economic Research, 1990. 
Stock-markets, Financial Institutions, and Corporate Performance. In: DIMSDALE, Nicholas $\mathrm{H}$. and PREVEZER, Martha (eds.). Capital Markets and Corporate Governance, Oxford: Claredon Press, 1994.

MCKINNON, Ronald I. Money and Capital in Economic Development, Washington, DC: Brookings Institution, 1973.

MCKINNON, Ronald I. Financial Liberalisation in Retrospect: Interest Rate Policies in LDCs. In: RANIS, G. and SHULTZ, T.P. (eds.). The State of Development Economics: Progress and Perspectives, New York: Basil Blackwell, 1988.

MCWILLIAMS, Douglas and SENTANCE, Andrew. The Changing Relationship Between the Banks and Business in the UK. In: DIMSDALE Nicholas H. and PREVEZER, Martha (eds.). Capital Markets and Corporate Governance, Oxford: Claredon Press, 1994.

MODIGLIANI, Franco and MILLER, Merton. The Cost of Capital, Corporation Finance, and the Theory of Investment, American Economic Review, p. 261-295, June, 1958.

PAGANO, Marco. Financial Markets and Growth: An Overview. European Economic Review, 37, p. 613-622, 1993.

PATRICK, Harold Financial Development and Economic Growth in Underdeveloped Countries. Economic Development and Cultural Change, 14, p. 174-189, 1966.

POTERBA, James and SUMMERS, Lawrence. Time Horizons of American Firms: New Evidence From a Survey of CEOs. Unpublished Manuscript, Department of Economics: Massachusetts Institute of Technology, 1992.

ROBINSON, Joan. The Generalisation of the General Theory. In: ROBINSON, Joan. The Rate of Interest and Other Essays, London: Macmillan, 1952.

SCHNEIDER-LENNE, Ellen R. The role of the German Capital Markets and the Universal Banks, Supervisory Boards, and Interlocking Directorships. In: DIMSDALE, Nicholas H. and PREVEZER, Martha (eds.). Capital Markets and Corporate Governance, Oxford: Claredon Press, 1994.

SCHUMPETER, Joseph A. The Theory of Economic Development, Cambridge, MA: Harvard University Press, 1959.

SHAW, Edward S. Financial Deepening in Economic Development, New York: Oxford University Press, 1973.

SINGH, Ajit. The Stock Market, Economic Efficiency and Industrial Development. In ARESTIS, Philip and CHICK, Victoria (eds.). Finance, Development and Structural Change: Post-Keynesian Perspectives, Aldershot: Edward Elgar Publishing, 1995.

VINALS, Jose et al. Spain and the 'EC cum 1992' Shock. In: BLISS, Christopher and MACEDO, Jorge Braga de (eds.). Unity With Diversity in the European Community: The Community's Southern Frontier, Cambridge: Cambridge University Press, 1990.

WOODWARD, Robert. The Agenda, New York: Simon and Schuster, 1994.

ZYSMAN, John. Government, Markets and Growth. Financial Systems and the Politics of Industrial Change, Ithaca, NY: Cornell University Press, 1983. 


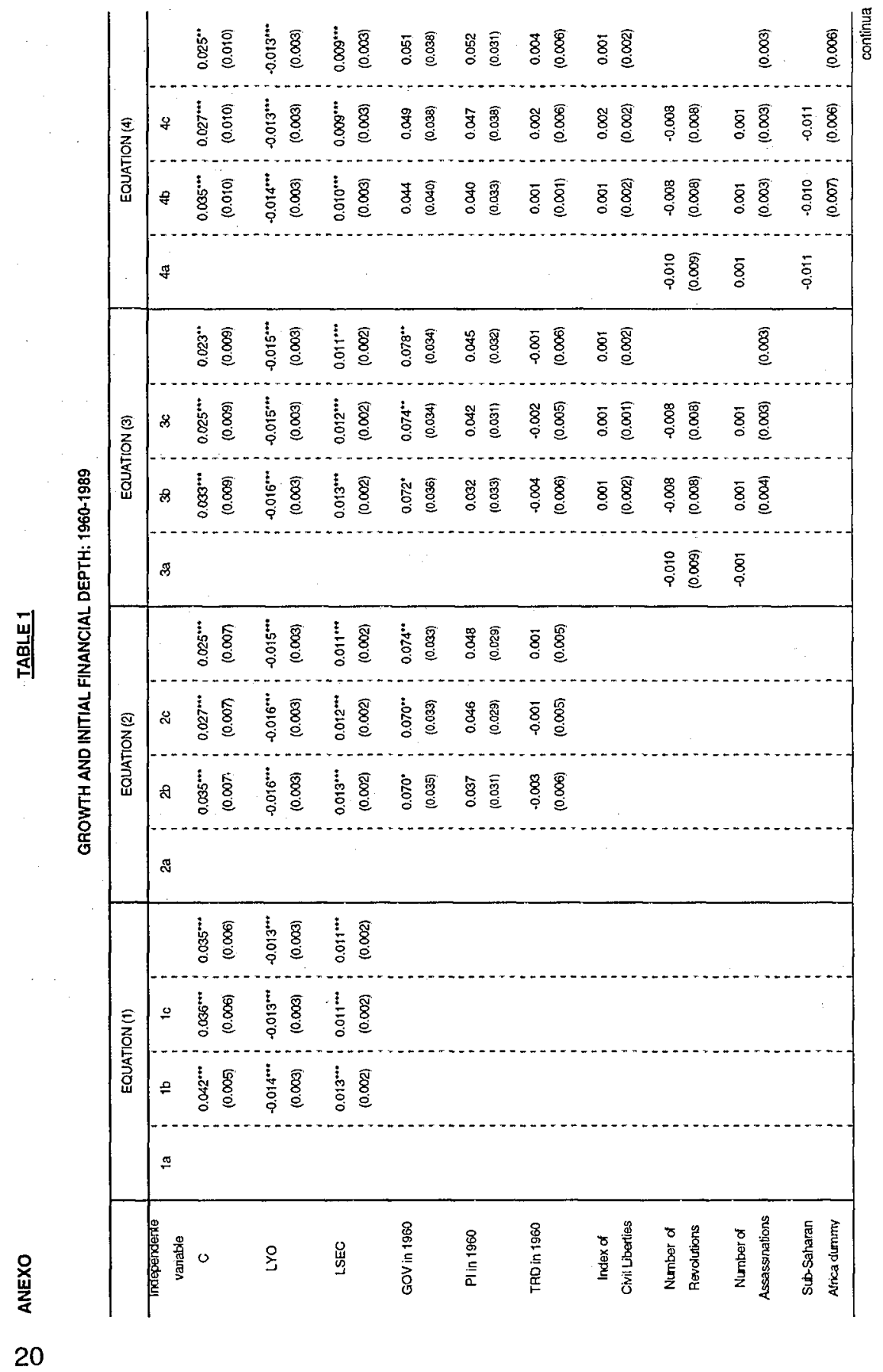




$$
\text { 恼 }
$$

